\title{
TRENDS IN OFFICIAL DEVELOPMENT ASSISTANCE TO DEVELOPING COUNTRIES AND POSSIBILITIES OF ALTERNATIVE FINANCING MECHANISMS
}

\author{
Talknice Saungweme, Lecturer \\ Great Zimbabwe University, Masvingo, Zimbabwe \\ E-mail: talknice2009@gmail.com, Phone:+263-772-685-837
}

\begin{abstract}
The study analyses trends in Official Development Assistance (ODA) to developing countries, mainly Africa, and possibilities of new financing instruments. Economies of most developing countries, especially those in Sub-Saharan Africa, are characterised by low investment flows, huge import bills and lower exports. Subsequently, development assistance is the major source of external finance and has taken the form of budget support, humanitarian and development finance. However, the noted fall in ODA in 2005, 2009 and 2012 might adversely impact directly on the attainment of millennium development goals in 2015. This negative trend in ODA is a result of a combination of factors such as economic constraints in the donor countries (for example, the debt crisis) and/or a new shift in financing mechanisms to developing countries.
\end{abstract}

\section{KEY WORDS}

Development assistance; Debt relief.

For some developing countries, especially in Africa, development assistance is a major source of external financing. Official development assistance (ODA) is funding, e.g. loans on concessional ${ }^{1}$ terms and grants, provided by rich governments and official agencies to developing countries. In as such, members of the Organisation of Economic Cooperation and Development (OECD), individual countries in Europe, multilateral financial institutions and other emerging international creditors (such as India, Brazil, South Africa and China) are the chief donor sources. The high volatility of aid as a source of development financial support and the interests of creditors attached to the funds are in there own respect a stumbling block to the intended development in the recipient countries. Mutual accountability of donated funds between the creditor and the recipient should exist and areas of development be agreed upon. Care has to be taken to ensure that financial resources are channelled towards economic development and improvement of social welfare in recipient nations.

Although the level of development aid has been on the rise since the 1990s, the increase is not complemented by proportional economic and social developments in recipient countries. This raises the question of where the funds are directed and how they (funds) are transformed into noticeable development. Also critical is the non consideration of debt relief as official development assistance but rather as a necessary foundation to promote growth.

Total ODA to developing countries grew from US $\$ 91.8$ billion in 1991 to US\$128 billion in 2011. In 2010, of the US131 billion ODA to developing countries, 35\% was directed to the Sub Saharan Africa (SSA). The graph below gives the trend in ODA to developing countries for the period 1981 to 2011.

Data for 2012 from OECD show that development aid fell by $6.3 \%$ in real terms from 2011. This was the third fall in ODA since 2005. The period 2005-2007 was marked by series of debt relief, mainly from multilateral and bilateral creditors and the Paris Club, to most developing countries through several debt relief initiatives, such the multilateral debt relief initiative (MDRI). The economic downturn and austerity measures adopted in most donor countries had a direct adverse impact on development aid in 2009 and 2012, respectively.

\footnotetext{
${ }^{1}$ A loan is concessional if it constitutes grant element of atleast $25 \%$.
} 


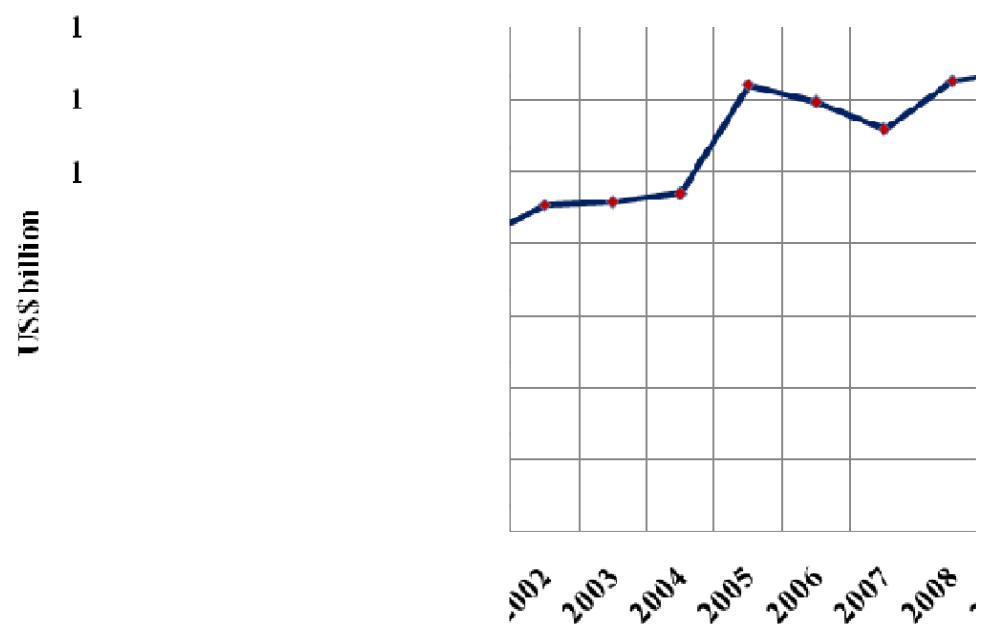

Picture 1 - Trend in ODA to developing countries (www.oecd.org)

产

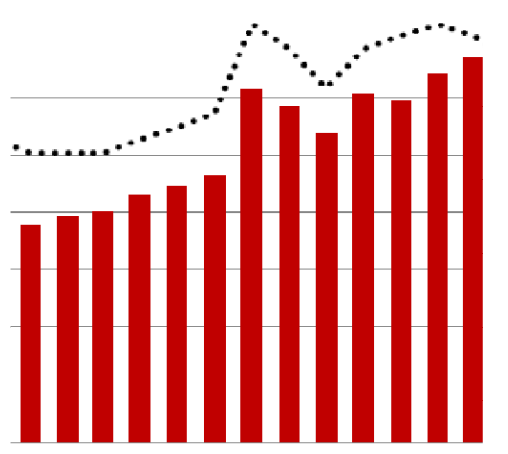

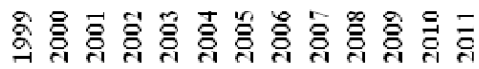

$\$ \mathrm{Bn} \quad \cdots \cdots \cdot \mathrm{ODA} / \mathrm{GN}$

Picture 2 - Trends in ODA by DAC countries (www.oecd.org)

$\begin{array}{clrr}1 & \text { Congo, Dem. Rep. } & 5522 & 11 \% \\ 2 & \text { Ethiopia } & 3563 & 7 \% \\ 3 & \text { Kenya } & 2474 & 5 \% \\ 4 & \text { Tanzania } & 2445 & 5 \% \\ 5 & \text { Mozambique } & 2047 & 4 \% \\ 6 & \text { Ghana } & 1815 & 4 \% \\ 7 & \text { Nigeria } & 1813 & 4 \% \\ 8 & \text { Uganda } & 1580 & 3 \% \\ 9 & \text { Cote d"lvoire } & 1437 & 3 \% \\ 10 & \text { Rwanda } & 1278 & 2 \% \\ & \text { Other recipients } & 27286 & 53 \% \\ & & 51261 & \mathbf{1 0 0} \%\end{array}$

Picture 3 - Top 10 DAC recipient countries in Africa, 2011; US\$ millions (www.oecd.org)

The African continent was negatively hit by these global movements in development aid from major donor countries. Total aid fell by $10 \%$ in 2011 to US $\$ 29$ billion. This was in 
part explained by the fall in United States' bilateral aid to $S_{S A}{ }^{2}$. The United States of America is the largest international donor country, and in 2011 and 2012, it contributed a total of US $\$ 31,4$ billion and US $\$ 30,5$ billion, respectively. In 2007 , the total ODA to least developed countries (LDCs) by DAC countries was US $\$ 31,9$ billion (representing $30.6 \%$ of total ODA), an amount according to the Brussels target should have been doubled by 2010 to meet millennium development goals by 2015.

In any given economy, the manufacturing sector contributes to the diversification of production, henceforth exports, which lessen dependence on volatile primary export of commodities. Export of commodities lead to unsustainable high import bill, export of jobs, macroeconomic instability and balance of payment challenges. According to DAC statistics of 2011 , however, approximately $59 \%$ (41\% going to health and population whilst $18 \%$ was for other social services) of aid was directed towards social services relative to $10 \%$ for production activities ${ }^{3}$. This means that LDCs will in future remain incapacitated to generate own financial resources to fund developmental activities without relying on unpredictable external funds.

The subsequent fall in ODA to LDCs, in both absolute and relative terms, justifies the existence of other international financing initiatives. For years, Development Financial Institutions (DFIs) have been in the business of providing finance to the public sector through loans, guarantees and equity investments. The process was, however, associated with misallocation of resources and corrupt activities by recipient governments. Henceforth, since 2000 , there has been a general increase in private sector financing citing it as the key driver to economic growth and hence poverty alleviation.

For instance, of the US\$134 billion disbursed by Development Assistance Committee (DAC) in 2011 (excluding debt relief), \$42 billion was directed to private sector investments and developments. ${ }^{4}$ The emergence of new creditors such as China, India, Brazil, South Africa, Middle East and Eastern Europe has also increased private sector financing. Such shift in the pattern of funding by creditors is backed by modern reasoning that developing countries can attain full economic and social development through combined public and private sector efforts. Of significance, however, is the need for a systematic model that tracks donor funds (regardless of source) and their impact on economic growth and social development in recipient nations. That is, DFls ought to fulfil their Busan ${ }^{5}$ and Paris declarations on aid transparency in order to strengthen mutual accountability and avoid duplication of efforts and resources.

\section{CONCLUSION}

Not only is the fall in absolute aid, in monetary terms, is of concern to Africa, but also the definition of aid, nature and conditions attached to it. Debt relief should not be viewed as development aid but rather as a necessary step that fosters the effectiveness of aid. Development aid should be one which enhances the production capacity of a country. With rich resource endowments, Africa needs not food handouts but to be capacitated with financial, physical capital, technology and the technical know-how. If fully and timeously equipped, the African continent will by 2030 be the new world creditor and exporter of finished products with moderate to high standards of living, thus, ceasing the current dependency on external funding. Yes, it is possible for Africa to be economically and socially self sufficient, independent of aid.

\footnotetext{
${ }^{2}$ In 2012, US bilateral aid to sub-Saharan Africa fell to US $\$ 8.8$ billion (-4.5\% in real terms compared to 2011), including debt relief.

${ }^{3}$ Source: OECD-DAC, World bank, www.oecd.org/dac/stats

${ }^{4} \mathrm{http}: / /$ www.globalhumanitarianassistance.org/the-2011-decrease-in-aid-from-dac-donors-a-new-era-3568.html

${ }^{5}$ Busan Partnership for Effective Development co---operation. Fourth high level forum on aid effectiveness, Busan, Republic of Korea, 29 November---1 December 2011
} 


\section{REFERENCES}

[1] ActionAid, 2005, Real Aid Report, ActionAid, United Kingdom.

[2] Aid Watch, 2009, Lighten the load, In a time of crisis, European aid has never been more important, Aid Watch Report, AidWatch, New York.

[3] Aid Watch, 2010, Penalty against Poverty: More and better EU aid can score Millennium Development Goals, Aid Watch Report, AidWatch, New York.

[4] Adams, Richard H. 2004. "Remittances and Poverty in Guatemala", World Bank Policy Research Working Paper 3418.

[5] AFD (Agence française de développement), et al. (2005), Pro-Poor Growth in the 1990s. Lessons and insights from 14 counties, Operationalizing Pro-Poor Growth Research Program 2005,World Bank,Washington DC.

[6] Arping. S., Morrison. A., Lóránth. G., (2008); Public Initiatives to Support Entrepreneurs: Credit Guarantees versus Co-Funding, University of Cambridge, University of Amsterdam, University of Oxford, March 7, 2008.

[7] Balkenhol, B, (1999); Guaranteeing bank loans to smaller entrepreneurs in West Africa, International Labour Review, vol.129, N2.

[8] Boza, Beatriz and Luke Haggarty (2006),"Utilising Public-Private Dialogue to Create a Market for Reform", case study presented at the International Workshop on Public Private Dialogue, 1-2 February, Paris.

[9] Collier, P. (2007) The Bottom Billion: Why the Poorest Countries Are Failing and What Can Be Done About It. Oxford: Oxford University Press.

[10] Dellacha, G. and te Velde, D.W. (2007) 'Analysis of Development Finance Institutions Financial Accounts'. Report commissioned by DFID.

[11] Development Initiatives, (2012), 'Official Development Assistance'.

[12] Dixit, A.K. and Pindyck, R. (1994) Investment Under Uncertainty. Princeton, NJ: Princeton University Press.

[13] International Development Association (2007), 'Aid Architecture: An Overview of the main trends in Official Development Assistance Flows.

[14] "What is the Impact of international Remittances on Poverty and Inequality in Latin America?", World Development 36(1): 89-114. 